\title{
SISMOGRAMAS DO CHOQUE: CONSIDERAÇÕES SOBRE O CHOQUE EM “TEORIA DA VANGUARDA", DE PETER BÜRGER, E EM "FILOSOFIA DA NOVA MÚSICA", DE THEODOR W. ADORNO
}

\author{
Eduardo Socha* \\ esocha@gmail.com
}

RESUMO Em “Teoria da vanguarda”, de Peter Bürger, o choque é compreendido como o artificio intencional dos movimentos de vanguarda contra a autonomia do esteticismo modernista, a fim de devolver a arte à práxis vital. Adotando uma perspectiva distinta, o choque, para Adorno, expõe antes a crise da experiência da formalização do tempo decorrente da incongruência entre as forças produtivas e as relações de produção na sociedade industrial, sendo que dois caminhos artísticos distintos derivam da inflexão histórica da crise da experiência. Em Schoenberg, na esteira do que Bürger classificaria como esteticismo, o choque seria amortizado pela expansão da linguagem musical, mediante seu registro. Em Stravinsky, o procedimento mecânico de golpes rítmicos e de montagem, em consonância com a profusão de vivências do choque, surge como elemento regressivo. Os choques não seriam dispositivos críticos, mas sismogramas de reações às mudanças da consciência subjetiva do tempo na modernidade. $O$ artigo procura enfatizar as premissas conflitantes entre Bürger e Adorno quanto à posição do conceito de choque, assim como as críticas de Bürger ao modernismo adorniano. 
Palavras-chave Adorno, Peter Bürger, música moderna, choque, vanguarda, montagem, Stravinsky, Schoenberg.

ABSTRACT In Peter Bürger's "Theory of the avant-garde", the concept of shock is rendered as an intentional avant-garde procedure against the institutionalization of art, i.e., against the autonomous criteria of modernist aestheticism, with the purpose of bringing art back to everyday life and vital praxis. From a quite different materialistic perspective, the concept of shock, in Adorno's musical writings, exposes the crisis of experience (Erfahrung) of the dissociation of time within two major streams of modern music, namely Schoenberg's school and Stravinsky's. This paper aims to point out the conflicting assumptions and consequences between Adorno and Bürger regarding their respective theoretical grasps on the concept of shock, as well as the critique to Adorno's musical modernism that Bürger addresses in this book.

Keywords Adorno, Peter Bürger, modern music, shock, avant-garde, construction, Stravinsky, Schoenberg.

\section{Choque em "Teoria da vanguarda"}

Em "Teoria da vanguarda" (1974), Peter Bürger associa o conceito de choque (Schock) ao "mais elevado princípio da intenção artística da vanguarda". ${ }^{1}$ A obra de arte vanguardista, em sua denegação de sentido imposta ao receptor, representaria uma reação concreta ao princípio de autonomia que prevalecia no quadro institucional das artes no final do século XIX. Tal princípio consolidou o que o autor chama de "esteticismo modernista", concepção que designa o progressivo afastamento da arte em relação à sociedade, a oclusão formal da arte sobre si própria. Por meio do choque, os movimentos históricos de vanguarda do início do século XX (principalmente o dadaísmo, o início do surrealismo e o futurismo russo) procuravam então demover o esteticismo, ambicionando com isso uma redefinição do papel social da arte. Tais objetivos haviam sido parcialmente motivados pela própria redução das possibilidades expressivas que sustentavam a prerrogativa da arte pela arte no esteticismo. Em função da disponibilidade integral de estilos e de procedimentos do passado, o imperativo do estranhamento, do deslocamento 
abrupto de signos induzido pelo choque, forneceria um modo privilegiado para a transposição da arte à práxis vital:

Esse choque é intencionado pelo artista de vanguarda, que mantém a esperança de, graças a essa privação de sentido, alertar o receptor para o fato de a sua própria práxis vital ser questionável e para a necessidade de transformá-la. ${ }^{2}$

O desejo vanguardista de criar novos modos de sensibilização capazes de transformar o cotidiano apontava tanto para a modificação da estrutura social de recepção da arte quanto para a destruição da ideia tradicional de obra (os ready-mades de Duchamp e a "escrita automática" dos surrealistas seriam exemplos diretos de tal intenção). Sob a perspectiva da estética da recepção de Bürger, o choque - realizado mediante os expedientes formais de montagem, bricolagem e acaso - seria, portanto, não apenas o mais elevado princípio da vanguarda como também seu principal dispositivo político.

No entanto, o projeto que visava desestabilizar a instituição arte, ${ }^{3}$ bem como a ideia de obra, resultou em fracasso, tendo em vista a posterior coexistência do princípio de autonomia com o arcaico e o pré-moderno. Bürger sugere que o ataque dos movimentos de vanguarda, em que pese sua tentativa de ruptura em bloco com toda a tradição (e não apenas com um sistema específico de representação), acabou paradoxalmente fortalecendo os alicerces da instituição arte, viabilizando inclusive a ampliação de seu repertório formal. Ou seja, se as vanguardas deixaram em aberto a possibilidade de transformação da ordem social por meio do choque, seu gesto de ruptura revelou-se, em contrapartida, bastante proveitoso para o subsistema social da arte e para seus mecanismos de distribuição. Esse fenômeno ficaria visível na assimilação "domesticada" dos procedimentos da vanguarda pela neovanguarda, no processo contraditório e irônico de "museificação" do objet trouvé de Duchamp; ${ }^{4}$ ao legitimar o choque como um dos paradigmas constitutivos das obras no século $\mathrm{XX}$, o aparato institucional preservou sua função tradicional de definir o que é arte, ou melhor, de determinar "o efeito ou a carência de efeito de arte" em geral.

2 Ibidem, p. 158: "A obra vanguardista não cria uma impressão total, condição para uma interpretação de seu sentido, nem confere clareza à impressão que, por ventura, venha se produzir no retorno às partes individuais, uma vez que estas não se encontram mais subordinadas a uma intenção da obra. O receptor experimenta essa denegação de sentido como choque."

3 Trata-se do conceito principal de "Teoria da vanguarda". Na visão do autor, a "instituição arte" estabelece as condições contextuais de recepção das obras numa determinada sociedade (em determinadas classes ou camadas sociais); ela "determina a função das objetivações culturais". Para uma definição precisa, ver Bürger, 2009, p. 39.

4 Ibidem, p. 120: "A instituição arte acabou por se mostrar resistente ao ataque vanguardista"; e mais adiante, "[o objet trouvé] perde seu caráter antiartístico, tornando-se obra autônoma, ao lado das outras, no museu" (ibidem, p. 122). 
Bürger encaminha diversas objeções à reflexão de Adorno sobre o modernismo e sobre o choque. Entre elas, a de que Adorno teria compreendido esse gesto de ruptura das vanguardas, gesto único e datado, como o princípio geral de desenvolvimento do modernismo. ${ }^{5}$ Por negligenciar a centralidade da instituição arte, Adorno não teria relativizado, por exemplo, a emergência histórica da categoria de "novo" e de autonomia, estendendo, de maneira retrospectiva, o impulso específico proveniente das vanguardas à totalidade do percurso estético desde o modernismo. Grosso modo, Adorno não soube perceber a diferença fundamental entre, por um lado, o projeto do esteticismo modernista e, por outro, aquele das vanguardas históricas, que se colocavam justamente contra o modernismo. Como Bürger adverte no livro, sob o termo "modernidade artística", Adorno entende o amplo período que inclui os "antecedentes dos movimentos de vanguarda (desde Baudelaire), os próprios movimentos e a neovanguarda". ${ }^{6}$ Tal indistinção deliberada entre modernismo e vanguarda - uma falta de precisão conceitual talvez surpreendente - privaria então a filosofia adorniana de admitir a historicidade de categorias estéticas, como a autonomia, o novo, a autoria, bem como de reconhecer certa transição funcional da instituição arte.

Entre os objetivos de Bürger, predomina aquele de apontar a alteração das condições estruturais de recepção e distribuição da arte, cuja visibilidade se tornou possível com as vanguardas. Assim, a irrupção do choque como dispositivo vanguardista seria o indício do estágio final de autocrítica do subsistema social da arte, motivado pelo próprio desenvolvimento do esteticismo, o que deveria levar à sua superação histórica. Se "Teoria da vanguarda" investe contra a concepção adorniana de modernismo pela adesão desta ao princípio de autonomia, é porque, segundo o autor, tal princípio obscurece o debate materialista sobre a função social da arte, suas condições específicas de recepção em cada momento histórico: "Adorno renuncia a uma análise da função, porque supõe, por trás disso, a tentativa de submeter a arte a fins estabelecidos fora dela". ${ }^{7}$ A problemática da função, em Adorno, estaria "amplamente desfocada", ${ }^{8}$ pois a hipóstase da autonomia orientaria todo o trajeto de sua especulação filosófica sobre as obras.

Bürger compreende, portanto, a categoria de autonomia como ideológica, no sentido do jovem Marx; ${ }^{9}$ ela congrega ao mesmo tempo um momento de

9 cf. Ibidem, "Seção II - Autonomia da arte na sociedade burguesa", em especial, p. 82 e pp. 100-101. 
verdade, ao tornar reconhecível o desenvolvimento histórico real de afastamento da arte em relação à práxis vital, induzido pelo esteticismo modernista, e um momento de inverdade, "ao hipostasiar esse estado de coisas, produzido historicamente, como 'essência' da arte", ${ }^{10}$ ou seja, ao tomar a particularidade de suas operações como qualidade universal. Nesse sentido, a constituição da categoria dissimularia seu processo de desenvolvimento, bloqueando o reconhecimento de si mesma como construto histórico admitido no interior da sociedade burguesa. A análise de Bürger apoia-se fundamentalmente na crítica da religião realizada por Marx, para quem o fenômeno religioso apresenta igualmente um momento de verdade (forma de protesto contra a miséria real do mundo social) e de inverdade (produção de realidade invertida). Sob esse aspecto, não é gratuita a atribuição do anátema ideológico à categoria de autonomia, quando se observa nela o princípio ritualizante do movimento esteticista, o próprio fundamento daquela "religião da arte" marcada pelo ideal de "poesia pura"."

Para Bürger, a maior conquista das vanguardas, em que pese sua esterilidade no campo da ação política, consiste na denúncia do cerne ideológico que norteou o esteticismo em sua crença na categoria de autonomia. Somente a análise da função social da arte, apoiada na centralidade da categoria de instituição arte, permitiria a distinção não ideológica entre o projeto do esteticismo modernista e aquele intencionado pelas vanguardas; tal distinção teria escapado, como vimos, à interpretação adorniana, que simplesmente dilui os movimentos de vanguarda a excursos do projeto modernista.

Entretanto, não se deduzem plenamente, ao menos não em "Teoria da vanguarda", as consequências que provêm da convergência entre modernismo e vanguarda no pensamento de Adorno. Em "Das Altern der Moderne", Bürger procura compreender, com efeito, a postura adorniana sob outro aspecto, associando a ela o acento crítico de "antivanguardismo". ${ }^{12}$ Para ele, a postura antivanguardista de Adorno estaria plenamente indiciada já no capítulo dedicado a Stravinsky de "Filosofia da nova música", no qual os procedimentos semelhantes àqueles do dadaísmo e do surrealismo, adotados

10 Ibidem, p. 101.

$11 \mathrm{lbidem}$, p. 68. Como previne o autor, não se deve confundir essa ritualização com a função primitiva da arte sacra, cujos propósitos residem em um culto externo a ela mesma.

12 Bürger, 2001, em especial o capítulo 3 - "O anti-vanguardismo na estética de Adorno". Esse capítulo, como declara o autor, resulta do desenvolvimento das formulações feitas no pequeno excurso do livro anterior, "Zur Kritik der idealistischen Ästhetik" (Suhrkamp, 1990), motivo pelo qual optamos por privilegiar aqui o capítulo e não o excurso. 
pela técnica de Stravinsky, seriam tomados como regressivos. ${ }^{13} \mathrm{~A}$ desconfiança adorniana quanto a métodos radicais de mudança das condições de recepção da arte - como o choque vanguardista - levaria o filósofo a considerar tais tentativas de ruptura como parte de um projeto intraestético que, todavia, se apresentava como falsa superação da aparência e não propriamente como ataque ao modernismo:

$\mathrm{O}$ ataque dirigido pelos movimentos de vanguarda contra o estatuto de autonomia da arte [...] só pode ser interpretado por Adorno como falsa superação da aparência (Schein) estética, e não como o lugar histórico de uma mudança radical (Umbruch) que permitiria pensar as contradições da arte no interior da sociedade burguesa. ${ }^{14}$

Com estratégia semelhante àquela utilizada em "Teoria da vanguarda", Bürger reafirma os limites do antivanguardismo adorniano pela sua insistência na lógica evolutiva do material artístico. Assim, critica-se novamente o fato de que tanto a noção de aparência quanto a noção de gênio, ambas vinculadas à ideia burguesa de autonomia, estariam atuando de maneira normativa no centro da teoria estética de Adorno.

É provável que o suposto "déficit sociológico", apontado pelo argumento de Bürger, proceda da divergência de método entre os autores a respeito do alcance social da arte e do significado do choque. De fato, Bürger mesmo avalia tal possibilidade: 'Caso os termos 'moderno' e 'vanguarda' sejam tomados como sinônimos, a tese do antivanguardismo de Adorno perde seu sentido". ${ }^{15}$ Podemos então conjeturar se parte das objeções de "Teoria da vanguarda" contra Adorno - apoiadas na hipótese das investidas da vanguarda contra a instituição arte e contra o esteticismo modernista nas artes visuais e na literatura - não resultaria de uma suspensão do enquadramento conceitual adorniano sobre o modernismo; em particular, sobre o modernismo musical, analisado com maior extensão pelo filósofo. A fim de expor o conflito entre as premissas dos autores, convém descrever como o conceito de choque se materializa nos dois extremos dialéticos de "Filosofia da nova música" (simbolizados por Schoenberg e Stravinsky), para, em seguida, expor as linhas gerais da crítica de Bürger em sua interpretação da reflexão adorniana.

13 Bürger, 2001, p. 42: "Besonders scharf hat Adorno die Abgrenzung von der Avantgarde im StravinskyKapitel der Philosophie der neuen Musik formuliert, das sich keineswegs nur gegen den neoklassischen Strawinsky richtet, sondern gerade auch gegen desse Frühwerk, das er nicht zu Unrecht in die Nähe des Dadaismus und des Surrealismus rückt”.

14 Ibidem, p. 41.

15 Ibidem, p. 33. 


\section{Choque e dissociação do tempo em "Filosofia da nova música"}

Percebemos que tanto Bürger quanto Adorno tomam diretamente de Benjamin o conceito de choque. Ao interpretar gestos e particularidades do cotidiano na vida moderna, registrados pela lírica de Baudelaire, Benjamin estabelece a oposição entre experiência (Erfahrung, "matéria da tradição" na qual, grosso modo, o registro de um acontecimento passaria pela intervenção da memória, do passado tanto individual quanto coletivo) e vivência (Erlebnis, a pura impressão de efeitos imediatos). Para o autor de "Sobre alguns temas em Baudelaire", a alteração da estrutura da experiência e da percepção subjetiva do tempo, dissociada por uma sequência de vivências no cotidiano na metrópole, é o fundamento que caracteriza a própria modernidade. Nesse sentido, a escrita "sismográfica" de Baudelaire manifestaria uma absorção mimética do choque, por meio da observação detida da multidão amorfa dos passantes na grande cidade, do trabalho mecânico do operário na "época da industrialização em grande escala", ou mesmo dos gestos pré-formados do "indivíduo ocioso" nos jogos de azar. ${ }^{16}$ Com efeito, Benjamin identificava em Baudelaire a "desintegração da aura na vivência do choque (Schockerlebnis)", desintegração que se tornou o preço necessário para "adquirir a sensação do moderno". ${ }^{17}$

Em carta de 1940 a Benjamin, Adorno declarava seu entusiasmo pela análise do choque empreendida especificamente nesse ensaio: “[...] a teoria do esquecimento e do choque possui estreita relação com algumas das minhas reflexões sobre a música, entre outras a que se refere à percepção das repetições". ${ }^{18}$ Tais reflexões comparecem em "Filosofia da nova música" (1949), no qual Adorno recorre à teoria de Benjamin para descrever a percepção mutilada e mecanizada do fluxo do tempo na música moderna: "mediante os choques, o indivíduo percebe de imediato sua nulidade diante da máquina enorme do sistema total". ${ }^{19} \mathrm{Na}$ linha de Benjamin, os choques corresponderiam aos sinais de um mundo que opõem forças produtivas (dominação da natureza) e relações de produção (dominação social), e que se refletem materialmente na música à maneira de sismogramas, reações da consciência no presente. ${ }^{20}$

16 Cf. Benjamin, 2000, cap. IX: "À vivência do choque, sentida pelo transeunte na multidão, corresponde a vivência do operário com a máquina".

17 Ibidem, p. 145. Ver também p. 111: "Assim, Baudelaire inseriu a experiência (Erlebnis, vivência) do choque no âmago do seu trabalho artístico".

18 Carta de 29 de fevereiro de 1940, in Adorno e Benjamin, 1995, p. 416.

19 Adorno, Philosophie de la nouvelle musique (Gallimard, 1962), doravante PNM, p. 163 (original em GS 12, p. 144).

20 Cf. Jimenez, 1973, pp. 161 e 175. 
Se lembrarmos que "Filosofia da nova música" foi concebida como excurso à "Dialética do esclarecimento", não estranharemos o paralelismo do conceito de choque com o atrofiamento da experiência subjetiva de tempo, ocasionada pela progressiva divisão social do trabalho na modernidade. Tal como descrito no livro publicado com Horkheimer,

Quanto mais complicada e mais refinada a aparelhagem social, econômica e científica, para cujo manejo o corpo já há muito foi ajustado pelo sistema de produção, tanto mais empobrecidas as vivências [Erlebnisse] de que ele é capaz. ${ }^{21}$

Desde já, um ponto importante da concepção adorniana de choque na música merece ser ressaltado: o choque pertence "ao fundamento de toda música nova", coincidindo com o "fim da experiência do tempo musical" e com as tendências de aniquilação da consciência subjetiva na modernidade. Ou seja, não apenas as peças da fase "primitivista" e da fase neoclássica de Stravinsky, mas também as peças da atonalidade livre de Schoenberg manifestariam a situação de impotência do indivíduo diante das forças da civilização em seu estágio técnico-industrial avançado. As duas tendências antinômicas da modernidade musical - simbolizadas por Schoenberg e Stravinsky - confirmariam o enfraquecimento da tensão entre sujeito e objeto na música, tensão implícita pelo menos desde o advento da tonalidade. Para Adorno, o caráter dialético do material da tonalidade condicionava essa tensão entre sujeito e objeto: por um lado, o material corresponde ao repositório dos esquemas formais e de modelos consolidados (o "espírito sedimentado" da tradição que projeta seu conteúdo social e objetivo); por outro, converte-se em obstáculo à autenticidade expressiva do compositor. Nesse sentido, podemos compreender em que medida "a confrontação do compositor com material é também confrontação com a sociedade", ${ }^{22}$

Ao atenuar as exigências materiais da tonalidade, a música moderna seria marcada por cesuras temporais que indicariam, na visão de Adorno, as intromissões das vivências do choque da vida moderna. É importante sublinhar novamente que o fenômeno da dissociação do tempo musical ocorreria nas duas vias do modernismo (e não somente no caso de Stravinsky, no qual prevalece um modo "rítmico-espacial" e regressivo de escuta). Ao contrário do que sugerem os títulos que compõem "Filosofia da nova música" ("Schoenberg

21 Adorno e Horkheimer, 1985, p. 47.

22 Adorno, PNM, p. 45. Para Adorno, a tensão entre sujeito e objeto na história da música encontraria na liberdade subjetiva e no rigor formal da sonata em Beethoven sua máxima enunciação. 
e o progresso" e "Stravinsky e a restauração"), o processo de dissociação do tempo manifesta-se também no expressionismo de Schoenberg:

A lei da harmonia complementar [de Schoenberg] implica o fim da experiência do tempo musical [...] Ela indica, com maior insistência do que outros sintomas, esse estado de a-historicidade musical. ${ }^{23}$

A miniatura expressionista da escola de Viena contrai a dimensão temporal, exprimindo um 'romance inteiro por um único gesto', enquanto que, nas mais poderosas construções dodecafônicas, o tempo se interrompe graças a um procedimento integral, desligado de qualquer ideia de desenvolvimento, pois nada que poderia se apresentar como desenvolvimento fora desse procedimento é tolerado. ${ }^{24}$

Desse modo, juntamente com a supressão da narratividade do discurso musical em decorrência dos vestígios da crise do sistema tonal, a reificação do tempo simbolizaria a introjeção do choque em seus extremos dialéticos:

O perecimento do tempo subjetivo na música, no meio de uma humanidade que faz dela mesma uma coisa, um objeto de sua própria organização, aparece como tão inevitável que se pode observar nos polos opostos da composição [Schoenberg e Stravinsky] um fenômeno similar. ${ }^{25}$

Sabemos que a reflexão materialista de Adorno se orienta pela premissa segundo a qual "o tempo que é imanente em cada música, sua historicidade interna, é realmente tempo histórico real, refletido como aparência (Erscheinung)" ${ }^{26}$ É assim que, em função do declínio da experiência (Erfahrung) na modernidade, torna-se visível, afinal, um fenômeno similar nos polos divergentes da nova música.

\section{1 "Erwartung" e o registro refletido do choque}

Adorno apresenta, contudo, uma diferença substantiva no que se refere à elaboração formal do choque nas composições. Essa diferença reside em processos técnicos distintos com que Schoenberg e Stravinsky exteriorizam as sequências do choque e, portanto, no alcance crítico que tais sequências adquirem no interior da forma musical. Adorno pretende desvelar as formalizações do choque por meio de uma análise concreta da dimensão rítmica, das variações de dinâmica, da progressão harmônica, da polifonia e da textura de obras. Esses elementos são articulados pela categoria de 
"subjetividade musical", na qual se conjugam uma teoria material e social das formas, bem como conceitos derivados da psicanálise.

Assim, no monodrama "Erwartung" (1909), uma das primeiras peças da atonalidade livre de Schoenberg, a música, segundo Adorno, "defendese contra as vivências do choque (Schockerlebnissen) ao representá-las (sie darstellt)". ${ }^{27}$ A fim de qualificar essa defesa contra o choque em Schoenberg, Adorno usa o termo "preparação/disposição para angústia" - Angstbereitschaft - descrito por Freud em "Além do princípio de prazer". ${ }^{28}$ Aqui novamente a referência a Benjamin pode ser percebida, em particular à seção III do ensaio sobre Baudelaire; comentando Freud, Benjamin afirma que, "quanto mais corrente se tornar o registro dos choques no consciente, tanto menos se deverá esperar deles um efeito traumático". ${ }^{29}$ Em função da Angstbereitschaft, o sujeito musical em "Erwartung" resiste aos choques ao fornecer a eles uma representação refletida, um registro expressivo único; consegue, em resumo, "transformá-los heroicamente (heroisch) em elementos de sua própria linguagem". ${ }^{30} \mathrm{O}$ sujeito empenha-se aqui na luta contra sua desagregação e permanece protegido durante a travessia dos choques, na medida em que "o registro sismográfico dos choques traumatizantes torna-se a lei técnica da forma musical, lei que impede toda continuidade e desenvolvimento". ${ }^{31}$ Para Adorno, a transcrição rigorosa e autêntica da angústia, decorrente das vivências do choque, amplia a linguagem musical e constitui a substância de toda obra de arte fragmentária - diferente de mecânica, conforme a classificação que veremos a seguir.

Em "Erwartung", com efeito, o andamento da peça altera-se de acordo com as manifestações pulsionais da personagem. Seu longo recitativo atemático, sem repetição ou pausa, resultante da extrapolação do princípio da variação em desenvolvimento, abandona centros tonais estáveis. Ao mesmo tempo, a falta de recorrência temática aliada ao rigor da construção polifônica encaminha um conceito renovado de expressão. Sob essa perspectiva, Dahlhaus argumenta que a poética de "Erwartung" fundamenta-se

27 Adorno, PNM, p. 163 (original em GS 12, p. 145).

28 Freud, 2010, p. 195: "[...] a preparação para a angústia, com o sobreinvestimento dos sistemas receptores, representa a última linha da barreira contra estímulos”. Segundo Marcio Seligman-Silva, a Angstbereitschaft encaminharia a "angústia que tem valor positivo de nos preparar para o desconhecido [...] um sinal na situação de perigo" (ver Seligmann-Silva, 2005, p. 66). Ou ainda Benjamin, 2000, p. 109: "A teoria psicanalítica procura entender a natureza do choque traumático a partir do rompimento da proteção contra estímulo. Segundo essa teoria, o sobressalto tem 'seu significado' na 'falta de predisposição/ preparação para a angústia'”.

29 Benjamin, 2000, p. 109, grifo meu.

30 Adorno, PNM, p. 163 (original em GS 12, p. 145).

31 Adorno, PNM, p. 53, grifo meu. 
no tratamento singular do canto com a polifonia orquestral, modificando o princípio expressivo cujo senso formal é definido por Adorno como "ausência de continuidade". O recitativo acompagnato que caracteriza o monodrama, uma "declamação musical acompanhada de motivos orquestrais descritivos", resulta em uma textura ao mesmo tempo atemática (tal como um recitativo) mas também polifônica no sentido camerístico; um denso trabalho de contraponto, com nítida diferenciação de vozes (linha vocal, voz instrumental principal, voz instrumental secundária e acompanhamento), preserva uma relevância hierárquica das vozes no discurso musical (o que remete diretamente à técnica contrapontística de Bach). Dahlhaus demonstra ainda que a recorrência de uma figura motívica de base composta por três notas (ré bemol - dó - lá) contribui também de maneira decisiva para a coerência estrutural da peça. ${ }^{32}$

Para Adorno, tais procedimentos forjam uma expressividade que se apresenta como "protocolo", "registro" de expressão (Ausdrucksprotokoll). ${ }^{33}$ No expressionismo, valoriza-se o "sentimento único criador da forma", a busca da expressão pura em vez de leis formais universais, esquemas impostos de cima para baixo. ${ }^{34}$ Isso significa que se, por um lado, a fragmentação impõe certa renúncia da percepção do caráter de aparência (Scheincharakter) da obra, por outro, essa renúncia não implica o abandono do princípio de construção formal, em última análise, de coerência orgânica entre sujeito e objeto. No caso de "Erwartung", a "segurança da forma revela-se meio de absorção dos choques": ${ }^{35}$ os choques dinamizam a dialética entre construção e expressão. De modo semelhante à elaboração formal do choque na poesia lírica de Baudelaire, Schoenberg produz um modo de representação musical da própria sequência de vivências fragmentárias na modernidade. Como observa Benjamin, "o fato de o choque ser amortecido e aparado pelo consciente emprestaria ao evento que o provoca o caráter de experiência (Erfahrung)". ${ }^{36}$ Em termos benjaminianos, poderíamos então dizer que o expressionismo de Schoenberg fornece ativamente o peso de uma experiência (Erfahrung) à natureza passiva das vivências (Erlebnissen) que definem a

32 Dahlhaus, 1978, pp. 149-155, passim.

33 E não mais como "expressiva" (Ausdrucksvoll). Cf. Adorno, PNM, p. 60.

34 Almeida, 2007, p. 34. A tendência "nominalista" do expressionismo aparece em diversas ocasiões no pensamento adorniano, como no ensaio "Vers une musique informelle", de 1961, em que se preconiza um modo de composição capaz de abandonar esquemas externos, ou que pelo menos os confronta de maneira inflexível, a fim de constituir sua própria substância musical (cf. Adorno, "Vers une musique informelle" in Quasi una Fantasia, GS 16, p. 497).

35 Adorno, PNM, p. 42 (original em GS 12, p. 37: "Die Sicherheit der Form erweist sich als Medium der Absorption von Schocks").

36 Benjamin, 2000, p. 110. 
modernidade. Nessa medida, a forma expressionista, que se esgota no interior da própria obra, distancia-se radicalmente dos procedimentos de montagem.

Este ponto é determinante na compreensão da relação entre choque, experiência e organicidade em "Filosofia da nova música": a resistência estrutural do sujeito, presente na atonalidade livre de "Erwartung", permite concluir que "a música expressionista ainda permanecia orgânica". ${ }^{37}$ Tal resistência não existiria no surrealismo: "expressionismo e surrealismo divergem na atitude em relação ao orgânico", propõe Adorno. Isso significa que, embora o expressionismo proceda da irracionalidade da organização social, a formalização fragmentária dessa irracionalidade ainda conserva um caráter orgânico. Em contrapartida, a irracionalidade do surrealismo, em sua "desagregação da unidade fisiológica do corpo", equivale à mímesis do antiorgânico, liga-se a uma "coisa morta" (Totes), no momento em que se deixa abandonar a um procedimento que "suprime a fronteira entre o corpo e o mundo dos objetos, para convencer a sociedade da coisificação do corpo. Sua forma é aquela da montagem, completamente estranha a Schoenberg". ${ }^{38}$

\section{2 "Sagração" e a absorção não refletida dos choques}

Adorno é categórico ao afirmar que, em Stravinsky, o sujeito musical não dispõe de Angstbereitschaft, de um mecanismo consciente de resistência à sequência dos choques. Ao contrário do expressionismo de "Erwartung", na "Sagração da primavera" (cujo programa, por sinal, sugere o colapso das forças individuais em nome da inexorabilidade de interesses ritualistas da coletividade), o sujeito musical sucumbe aos choques por meio de convulsões irrefletidas, sustos, sobressaltos que sancionam a falha da resistência ao choque. A transcrição dos choques é imediata, não refletida, pois o "tipo humano" que deriva da obra abstém-se de toda reflexão sobre si e admite que não pode elaborar o que lhe transcende. Desse modo, na "Sagração", ficaria celebrada, em vez de elaborada, a liquidação do sujeito:

O sujeito musical renuncia a se afirmar como sujeito, resignando-se em sofrer as convulsões; comporta-se como ferido, vítima de um acidente que não consegue absorver e que o repete constantemente nos sonhos. ${ }^{39}$

Vale a pena enfatizar uma importante nuança conceitual: sujeito e forma musical não estão necessariamente atrelados. Em Stravinsky, o sujeito 
musical identifica-se com a vítima, embora a forma musical se identifique objetivamente com a instância destrutiva, com o agressor. ${ }^{40}$ Enquanto que, no polo oposto, a forma musical em Schoenberg atua como Angstbereitschaft, como proteção para os choques aos quais o sujeito é igualmente submetido. A linguagem expressionista representaria, como vimos, uma proteção subjetiva de amortecimento dos choques; em Schoenberg, portanto, o sujeito converte suas vivências em experiência (Erfahrung), por meio do desenvolvimento consciente do material que tem como referente implícito a tonalidade.

Já para descrever o estado "anímico" do sujeito em Stravinsky, incapaz de se defender dos choques, são utilizadas categorias como "despersonalização", "ausência de intenção", infantilismo, catatonia. ${ }^{41}$ Como no estado catatônico de pessoas marcadas por um trauma, a desintegração do eu levaria à repetição de gestos e palavras que desestabilizam a coerência do discurso. Na visão de Adorno, a renúncia à elaboração formal em Stravinsky, reduzindo o trabalho do compositor à manipulação de resíduos da tonalidade, corresponde à renúncia à categoria de sujeito. A música de Stravinsky, torna-se, nesse sentido, "objetivada", estranha à consciência e alheia à história do "espírito". Poderíamos afirmar que, para Adorno, o gesto musical de Stravinsky fixa um conjunto de "conceitos sem intuição", no sentido daquele destemor que caracteriza o indivíduo sem Angstbereitschaft, conforme o seguinte aforismo de Minima moralia:

Quando o objeto da experiência vai além da proporção ao indivíduo este nem mesmo chega a percebê-lo, mas o registra imediatamente (unvermittelt) por meio do conceito sem intuição (durch den anschauungslosen Begriff), como algo externo e incomensurável, em relação ao qual ele se comporta tão friamente como o choque catastrófico faz com ele. ${ }^{42}$

Tecnicamente, as convulsões e os sobressaltos que dissociam a experiência do sujeito efetivam-se sobretudo no plano rítmico: ênfase nas síncopes e nas mudanças assimétricas do compasso, pulsação recorrente em ostinato, repetição de motivos isolados e rudimentares. O ritmo é, por assim dizer, hipostasiado como vetor estruturante da composição, o que esvazia a elaboração do conteúdo propriamente melódico e harmônico. Na medida em

40 Adorno, PNM, p. 151.

41 Evidentemente essa descrição não se refere ao estado subjetivo mental de Stravinsky compositor, ao contrário do que alguns comentadores (Boucourechliev e Knudszus, por exemplo) chegaram a sugerir. De fato, a dialética adorniana procura eliminar (em "Filosofia da nova música" pelo menos) toda interferência ligada à psicologia dos compositores.

42 Adorno, 2008a, §116, trad. Gabriel Cohn, com alterações. 
que a prática composicional de Stravinsky converge para essa fetichização do ritmo, despreza-se aquilo que Adorno chama de "organização total dos elementos" (Durchorganisation der Elemente). Ou seja, mesmo o emprego da dissonância e a politonalidade resultariam de um pensamento orientado ao fortalecimento da rítmica. Esse estilo composicional fica bastante evidente, por exemplo, no $2^{\circ}$ movimento da Sagração, Augúrios primaveris, ao longo do qual um único acorde dissonante que, segundo o próprio compositor, teria servido de inspiração para a peça como um todo ${ }^{43}$ - o acorde "augúrios" (consistindo na sobreposição de um acorde de mi bemol maior com sétima dominante e a tríade de fá bemol maior; ver Fig. 1) - é repetido 280 vezes e se desliga de toda função harmônica; ou ainda, no último movimento, "Dança sagrada - a eleita", em que o motivo melódico mais perceptível é um fragmento de seis notas (conjunto de três notas em cromatismo descendente repetido duas vezes). A obra de Stravinsky cultivaria então certa apatia em relação àqueles recursos técnicos que poderiam fornecer a sensação de continuidade do tempo: não há "transições, crescendos, diferença entre campo de tensão e repouso, entre exposição e desenvolvimento, entre pergunta e resposta". ${ }^{44} \mathrm{Na}$ leitura de Adorno, os expedientes que eliminam as expectativas funcionais da percepção de um contínuo temporal fazem da música de Stravinsky uma "escamotagem do tempo", uma obra "estática” que recusa desenvolver-se.

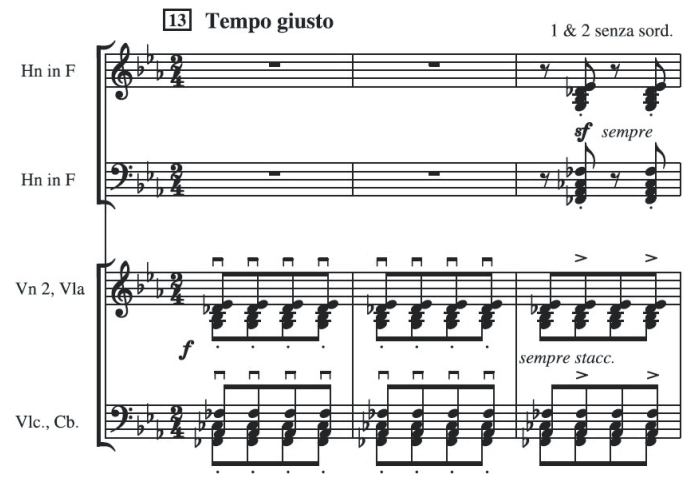

Figura 1 - Acorde "augúrios" no início do $2^{\circ}$ movimento ("Sagração") 
Além do fetichismo da rítmica, outro elemento destacado por Adorno como regressivo no tratamento dos choques refere-se, como vimos, ao uso da montagem, do recurso de "música sobre música", apresentado como paródia e orientado por uma lógica de desintegração do material. O excesso de citações musicais em Stravinsky revelaria não apenas sua rejeição deliberada ao desenvolvimento do material, mas o desejo de fazer passar por novo o que já estaria classificado, pré-formado. ${ }^{45}$ Nesse sentido, a "História do Soldado" é comparável às montagens oníricas dos surrealistas, feitas a partir de dejetos da vida cotidiana. A obra compõe-se de "montagens de material morto", "sequências sonoras danificadas", fragmentos de peças de salão, fanfarras, polcas, música de circo, tango, ragtime, marchas militares; sob esse aspecto, a comparação com os dadaístas sugerida por Bürger de fato não seria improcedente, se levarmos em conta que o compositor declarava aspirações semelhantes àquelas dos vanguardistas do início do século. ${ }^{46}$ Além disso, o retorno a formas arcaicas na fase neoclássica, indiferente ao estágio histórico do material, confirmaria o desejo de suspensão do próprio tempo histórico.

\section{Críticas de Bürger a Adorno: incompatibilidade entre as concepções de choque}

A partir das análises imanentes de Schoenberg e Stravinsky, Adorno propõe uma classificação com três tipos de obra: ${ }^{47}$ a) obra de arte fechada (geschlossene Kunstwerk), que oculta seu processo de produção reafirmando seu caráter de aparência, caso de Beethoven; b) obra de arte fragmentária (fragmentarische), alçada a objeto de conhecimento, única capaz de liberar conteúdo crítico, por expor em sua forma as contradições sociais e a angústia do sujeito, como o expressionismo de Schoenberg, que ainda preserva organicidade; c) obra de arte mecânica (mechanische), de índole fascista, pela adesão ao ritmo motorizado e à repetição de fórmulas, ligado ao inorgânico, como em Stravinsky.

Essa divisão tripartite sugerida por Adorno dificilmente se coaduna com a divisão binária de Bürger entre obra de arte orgânica (visando à produção de aparência de algo natural, construída segundo um padrão sintagmático no qual os detalhes e o todo formam uma unidade dialética) e obra de arte não orgânica

45 Adorno, PNM, p. 115.

46 Cf. Almeida, 2007, cap. 5 - "Dadá"; ver também as considerações de Bürger sobre o antivanguardismo de Adorno (em "Das Altern der Modern"), para uma aproximação entre Stravinsky e o dadaísmo.

47 Adorno, PNM, p. 134, nota 1. 
(ligada ao conceito de alegoria de Benjamin, cujo dispositivo conceitual seria principalmente o choque). ${ }^{48}$ Podemos finalmente nos perguntar se tal incompatibilidade não teria levado Bürger a apresentar de maneira imprecisa, em "Teoria da vanguarda", a visão adorniana de modernismo.

Em diversos momentos de "Teoria da vanguarda", notamos os efeitos de tal inadequação. Bürger ressalta, por exemplo, que, pelo fato de a filosofia de Adorno ainda pertencer a certa tradição do esteticismo, não se desvencilhou da crença ideológica no princípio da autonomia, no desligamento progressivo da arte à práxis vital. ${ }^{49}$ No entanto, sabemos que a concepção de "arte pela arte" que regula o esteticismo é de fato problematizada por Adorno, pois se reconhece tacitamente a contradição interna da ideia de autonomia: a autonomia da arte depende, afinal, de um momento social heterônomo que lhe confere legitimidade, vinculada, por sua vez, à ideia burguesa de liberdade. ${ }^{50}$ Adorno não deduz, portanto, uma história linear da arte, pois em sua concepção de obra se efetua um movimento de oscilação conflitante entre "fato social", produto do trabalho social do espírito, e autonomia, reflexão sobre suas formas internas (atingida com o aburguesamento da arte). Para Adorno, a autonomia, na medida em que se apresenta como crítica e negação determinada ao mundo social empírico, não deveria ser confundida com a autotelia da "arte pela arte".

Em outra passagem, Bürger denuncia o uso ideológico da categoria do novo por parte de Adorno, bem como sua negligência quanto às modificações das condições da recepção da arte. Considera que o modernismo, para Adorno, não somente teria rompido com a continuidade do desenvolvimento de uma tradição específica (por exemplo, a invenção de um gênero, como o Lied, e sua modificação posterior no século XIX), mas teria realizado uma ruptura com toda a tradição. ${ }^{51}$ Segundo Bürger,

Exatamente este é o ponto a ser criticado na utilização adorniana da categoria do novo. Adorno tende a transformar a ruptura com a tradição assinalada pelos movimentos históricos de vanguarda, ruptura historicamente única, em princípio de desenvolvimento da arte moderna. ${ }^{52}$

48 No último capítulo de "Teoria da vanguarda", Bürger considera que tal oposição passou a ser problemática após os ataques das vanguardas à instituição arte.

49 Bürger, 2009, p. 35.

50 Jarvis, 1988, pp. 120-121. Ver também o próprio Adorno em "Ästhetische Theorie": "Ihre Autonomie [der Kunst], Verselbständigung der Gesellschaft gegenüber, war Funktion des seinerseits wieder mit der Sozialstruktur zusammengewachsenen bürgerlichen Freiheitsbewußtseins" (GS 7, p. 334).

51 Bürger, 2009, p. 126.

52 Ibidem, p. 127. 
Porém, como vimos, Adorno evita compreender o ato de ruptura vanguardista como "ruptura com a tradição", optando por tomá-lo antes como falsa superação da aparência. Mesmo a ruptura das obras fragmentárias do expressionismo conserva "a tradição dos critérios técnicos diante da barbárie crescente". ${ }^{53}$ Em que pese sua recusa a estruturas da tonalidade, por exemplo, o expressionismo musical resultaria, por um lado, das consequências formais do cromatismo e da modulação contínua de Wagner e, por outro, do princípio de variação em desenvolvimento, proveniente do romantismo de Brahms. Além disso, a insistência na radicalidade do estilo composicional de Mahler indica que, para a estética de Adorno, o "estado histórico do desenvolvimento das técnicas" não assegura necessariamente o avanço das forças produtivas da música (aqui subentendidas no conceito de material). Vale a pena insistir que, na acepção adorniana de arte como "fato social", um regime teleológico e evolutivo de história da arte dificilmente encontra lugar.

O texto de Bürger também parece superestimar o lugar que Adorno atribui ao procedimento de montagem no modernismo:

[...] as considerações de Adorno sobre o significado da montagem para a arte moderna constituem [para ele] pontos de referência importantes para a compreensão do fenômeno. Adorno aponta o caráter revolucionário do procedimento [...] Mas é questionável a possibilidade de se atribuir ao procedimento artístico da montagem também um significado político, como o faz Adorno. ${ }^{54}$

Entretanto, como vimos na crítica a Stravinsky, Adorno não aponta o caráter revolucionário do procedimento. Notamos que, no léxico adorniano, obra de arte antiorgânica, mecânica, tende à regressão. A ideia de compor "música a partir de música" remontaria de fato a Mozart em suas citações de Haendel, ou mesmo a Mahler. Contudo, quando elevada a princípio de estruturação, por meio da exposição de um material previamente codificado sem tensões com a história, do excesso de citações de sequências sonoras, a ideia de montagem musical abdicaria da construção orgânica e intencional de sentido, denunciando um caráter reacionário de eliminação do polo subjetivo da composição. ${ }^{55}$

Um quarto aspecto da crítica de Bürger a Adorno refere-se à própria denegação de sentido. Bürger afirma que "quando Adorno interpreta a negação da síntese como negação de sentido, é preciso lembrar que mesmo a denegação 
de sentido representa ainda um tipo de atribuição de sentido". ${ }^{56}$ Em "Filosofia da nova música", entretanto, a denegação de síntese em Schoenberg é de fato compreendida como "esclarecedora" da situação social de um "mundo privado de sentido". A denegação intencional de sentido (distinta da montagem) que emerge da expressão fragmentária em Schoenberg constitui, para Adorno, um sentido de segunda ordem. Tal característica também é descrita nas passagens de "Teoria estética" relativas ao formalismo e à crise de sentido:

a emancipação das obras de arte relativamente ao seu sentido torna-se esteticamente rica de sentido, logo que se realiza no material estético [...] As obras de arte, que se despojam da aparência de todo aspecto significante, nem por isso perdem sua semelhança com a linguagem [...] As obras de mais elevado nível formal, desprovidas de sentido ou a ele alheias, são, pois, mais do que absurdas, porque seu sentido cresce na negação do sentido. ${ }^{57}$

Os exemplos acima sugerem que essa divergência quanto à posição do problema do choque, divergência não enunciada por Bürger em seu livro de 1973, instigaria a crítica em relação à validade da reflexão de Adorno para se compreenderem as manifestações ulteriores de vanguarda. Tal divergência parece comprometer, no entanto, o alcance do empreendimento, pois, ao simplesmente contrapor obra de arte orgânica e obra vanguardista nãoorgânica (esta que, posteriormente, foi reassimilada pela instituição, ampliando o campo semântico de obra de arte), a interpretação de Bürger tende a obscurecer a dialética inscrita na própria modernidade, ressaltada por Adorno, entre progresso e regressão, autonomia e heteronomia, obra de arte fragmentária e mecânica. Longe de ser o "déficit" insinuado por Bürger, a ausência de demarcação entre modernismo e vanguarda em Adorno sugere, na realidade, o deslocamento da compreensão do mesmo fenômeno para outro eixo conceitual.

Por caminhos distintos, outros comentadores também observam a insuficiência da interpretação de Bürger. Max Paddison, por exemplo, discorda da insensibilidade teórica de Adorno em relação às mudanças estruturais das condições de recepção das obras, salientando, pelo contrário, a força de sua especulação sociológica ao tratar dos mecanismos de distribuição da arte. ${ }^{58}$ Lambert Zuidervaart, por sua vez, mostra que as objeções de Bürger à categoria

56 Bürger, 2009, 156.

57 Adorno, 2008b, p. 235. (Original em GS 7, 231: "Die sinnlosen oder sinnfremden Werke des obersten Formniveaus sind darum mehr als bloß sinnlos, weil ihnen Gehalt in der Negation des Sinns zuwächst".) 58 Cf. Paddison, 1998, Cap. 7. 
de autonomia em Adorno são invalidadas por suas próprias premissas:59 "Teoria da vanguarda" deseja recusar toda estética normativa, baseada em critérios que derivam do princípio de autonomia, mas requer a estabilidade de outro esquema normativo para, então, historicizar a estética adorniana em chave crítica. ${ }^{60}$ Também na leitura de Richard Murphy a posição do problema da autonomia no modelo de Bürger incide na petição de princípio: sua teoria pressupõe o distanciamento crítico do objeto a ser criticado (a primazia da autonomia), logo, certo afastamento da práxis vital. Assim, a possibilidade de constatação crítica da alteração da função social da arte torna-se viável apenas por meio da mesma autonomia que deveria ser denegada. ${ }^{61}$

Por fim, segundo nossa hipótese, a diferença semântica quanto à categoria de choque prenuncia a vulnerabilidade crítica de "Teoria da vanguarda". Se os exemplos acima de fato apontam para uma efetiva incompatibilidade conceitual, podemos supor que a origem dessa tensão se localiza na tentativa de subjugar a dinâmica histórica específica da música, arte na qual Adorno fundamenta com maior rigor sua reflexão sobre o modernismo, às dinâmicas históricas das artes visuais e da literatura, a partir das quais Bürger procura delimitar, afinal, o surgimento do choque como o dispositivo crítico e político das vanguardas.

\section{Referências}

ADORNO, T. W. "Digitale Bibliothek Band 97: Theodor W. Adorno: Gesammelte Schriften". Berlin: Directmedia-Surkhamp, 2003. . "Philosophie de la nouvelle musique". Paris: Gallimard, 1962. ."Essays on Music". Berkeley: University of California Press, 2002.

59 Zuidervaart, 1990, p. 61. Não seria o caso de examinar os méritos do artigo de Zuidervaart, cujo propósito é sistematizar e confrontar as normatividades estéticas de Bürger e Adorno para dela extrair seu modelo particular de "normatividade complexa" (cf. seção "Complex normativity", p. 74). De todo modo, embora o artigo descortine a adesão utópica de ambos os autores ao princípio de autonomia, consideramos no mínimo reticente a apreciação de aspectos centrais da reflexão adorniana. Zuidervaart declara, por exemplo, que o conceito de autonomia em Adorno é mal elaborado (p. 69), pois, assim como a arte autônoma também serve a certos "propósitos humanos mais diretamente do que outras instituições na sociedade" (p. 70), a arte heterônoma desafia mais o status quo do que autônoma (p. 71). Aqui ficaria em segundo plano não só o debate entre "arte engajada" politicamente e "arte pura" que Adorno enfrentou em diversos ensaios, como "O artista como representante, Museu Valéry-Proust", ou mesmo em "Teoria Estética"; mas ficaria em segundo plano também o fato de que, para Adorno, a arte autônoma tensiona a estrutura social exclusivamente por meio dos recursos desta. Como negação determinada, o potencial crítico da arte autônoma depende concretamente da existência institucional para se realizar.

$60 \mathrm{Ibidem}$, p. 72: "If valid aesthetic norms can no longer be posited, it becomes hard to determine why Bürger's standpoint toward Adorno's norms is any more valid than any other".

61 Murphy, 1999, p. 27. 
ADORNO, T. W. "Minima moralia". Tradução de Gabriel Cohn. Rio de Janeiro: Azougue Editorial, 2008a.

. "Teoria Estética". Lisboa: Edições 70, 2008b.

ADORNO, T. W., BENJAMIN, "W. Theodor W. Adorno - Walter Benjamin: Briefwechsel 1928-1940”. Frankfurt am Main: Suhrkamp, 1995.

ADORNO, T.; HORKHEIMER, M. "A Dialética do Esclarecimento: fragmentos filosóficos". Rio de Janeiro: Jorge Zahar, 1985.

ALMEIDA, J. "Crítica dialética em Theodor Adorno - música e verdade nos anos vinte". Cotia: Ateliê Editorial, 2007.

BENJAMIN, W. "Obras escolhidas III - Charles Baudelaire, um lírico no auge do capitalismo". São Paulo: Brasiliense, 2000.

BÜRGER, P. "Teoria da vanguarda”. São Paulo: Cosac Naify, 2009.

. "Das Altern der Modern". Frankfurt am Main: Suhrkamp, 2001.

. "Zur Kritik der idealistischen Ästhetik”. Frankfurt am Main: Suhrkamp,

1990.

CHUA, D. "Rioting with Stravinsky - a Particular Analysis of the Rite of Spring". Music Analysis, 26, pp. i-ii, 2007.

DAHLHAUS, C. "Schoenberg and the new music". Cambridge: Cambridge University Press, 1978.

FREUD, S. "Para além do princípio do prazer". São Paulo: Companhia das Letras, 2010.

JARVIS, S. “Adorno: a Critical Introduction”. New York: Routledge, 1988.

JIMENEZ, M. “Adorno: Art, Idéologie et Théorie de l'Art”. Paris: Union Générale D’Éditions, 1973.

MURPHY, R. "Theorizing the Avant-Garde: Modernism, Expressionism, and the Problem of Postmodernity". Cambridge: Cambridge University Press, 1999.

PADDISON, M. “Adorno's Aesthetics of Music". Cambridge: Cambridge University Press, 1998.

SELIGMANN-SILVA, M. "O local da diferença: ensaios sobre memória, arte, literatura e tradução". São Paulo: Ed. 34, 2005.

ZUIDERVAART, L. "The Social Significance of Autonomous Art: Adorno and Bürger". Journal of Aesthetics and Art Criticism, 48, pp. 61-77, 1990. 